\title{
Hydrogenation Conditions which Do Not Result in Formation of Cracks During Hydrogen Charging Process of Steels
}

Gejza Rosenberg, Iveta Sinaiová

Institute of Materials Research, Slovac Academy of Sciences, Watsonova 47, 04001 Košice, Slovac Republic, grosenberg@saske.sk, isinaiova@saske.sk

It is well known that the susceptibility of steels to hydrogen embrittlement is markedly dependent on hydrogenation conditions of samples. In this contribution are presented key results of relatively extensive studies oriented to examination of the effect of electrolytic hydrogen charging conditions (charging time and current density) on the hydrogen embrittlement of steels evaluated by the slow three point bend tests, micro- and macro-hardness tests. Various kinds of industrially produced hot rolled steel strips were tested (structural steel, dual phase and HSLA steels). The major aim of this study was to determine the hydrogenation conditions that do not result in the formation of defects such as microcrack or voids (in terms of absence of defects found by using optical microscopy) during hydrogen charging process.

Keywords: hydrogen charging process, hardness, mechanical properties, low carbon steels, hydrogen-induced cracking

\section{Acknowledgements}

This research was supported by the Grants No. 2/0176/15 of the Grant Agency of Ministry of Education and Slovak Academy of Sciences (VEGA).

\section{References}

[1] FROHMBERG, R. P., BARNETT, W. J., TROIANO, A. R. (1954). Delayed Failure and Hydrogen Embrittlement in Steel, Case Institute of Technology, WADC, Wright- Patterson Air Force Base, Ohio, Technical Report 54-320, June 1954, pp. 1-52.

[2] LOIDL, M., KOLK, O., VEITH, S., GOBEL, T. (2011). Characterization of hydrogen embrittlement in automotive advanced high strength steels, Mat.-wiss. u.Werkstofftech. $42 / 12$ (2011) 1105-1110

[3] VASKOVÁ, I., JANČOK, J., HRUBOVČÁKOVÁ, M., CONEV, M. (2015). Hydrogen Removal from Liquid Metal, Manufacturing Technology, 15/4, (2015), 737-739.

[4] LIU, Q., ATRENS, A. (2013). A critical review of the influence of hydrogen on the mechanical properties of medium-strength steels, Corros Rev, 31/3-6 (2013) 85-103.

[5] SOFRONIS, P. RITCHIE, R. (2007). Hydrogen induced material degradation: brittle decohesion, Hydrogen-Induced Material Degradation: Brittle Decohesion Versus Plastic Flow Localization, Award ID: NSF/DMR 0302470 (06/2003-06/2007) pp. 1- 3.

[6] WANG, R..(2009). Effects of hydrogen on the fracture toughness of a X70 pipeline steel, Corrosion Science 51 (2009) 2803-2810.

[7] CAPELLE, J., GILGERT, J., DMYTRAKH, I., PLUVINAGE, G. (2011). The effect of hydrogen concentration on fracture of pipeline steels in presence of a notch, Engineering Fracture Mechanics 78 (2011) 364-373.

[8] DAYAL, R.K., PARVATHAVARTHINI, N. (2003). Hydrogen embrittlement in power plant steels, Sadhana, 28/3-4 (2003) 431-451.

[9] MICHLER, T., NAUMANN, J. (2010). Microstructural aspects upon hydrogen environment embrittlement of various bcc steels, Int. J. Hydro. Energy, 35 (2010) 821-832.

[10] LOIDL, M., KOLK, O. (2011). Hydrogen Embrittlementin HSSs Limits Use in Lightweight Body, Advanced Materials \& Processes, 2011, March, pp.22-25.

[11] BRIOTTET, L., MORO, I., LEMOINE, P. (2012). Quantifying the hydrogen embrittlement of pipe steels for safety considerations, Int. J. Hydrogen Energy, 37 (2012) 17616-17623.

[12] MIRESMAEILI, R., LIU, L., KANAYAMA, H. (2012). A possible explanation for the contradictory results of hydrogen effects on macroscopic deformation, International Journal of Pressure Vessels and Piping, 99-100 (2012) $34-43$.

[13] SONG, J. CURTIN, W.A. (2013). Atomic mechanism and prediction of hydrogen embrittlement in iron, Nature Materials, 12 (2013) 145-151. 
[14] ZHAO, Y. SEOK, M.I. CHOI, I.C., LEE, Y.H., PARK, S.J., RAMAMURTY, U., SUH, J.Y., JANG, J.I. (2015). The role of hydrogen in hardening/softening steel: Influence of the charging process, Scripta Materialia 107 (2015) 46-49.

[15] PEREZ ESCOBAR, D., MINAMBRES, C., DUPREZ, L., VERBEKEN, K., VERHAEGE, M. (2011). Internal and surface damage of multiphase steels and pure iron after electrochemical hydrogen charging, Corros. Sci. 53 (2011) 3166-3176.

[16] LIU, Q., ATRENS, A.D., SHI, Z. VERBEKEN, K., ATRENS, S. (2014). Determination of the hydrogen fugacity during electrolytic charging of steel, Corrosion Science 87 (2014) 239-258.

[17] IOST, A., VOGT, J.B. (1997). Hardness variation in a cathodic hydrogen-charged austenitic stainless steel, Scr. Mater., 37 (1997) 1499-1504.

[18] AL-MARAHLEL, GHAZI S., EL-AMOUSH, AMJAD S. (2005). Effect of cathodically charged hydrogen on the microhardness of pure copper, American Journal of Applied Sciences, 2 (2005) 526-532.

[19] GLOWACKA, A., WOZNIAK, M., SWIATNICKI, W. (2004). Reviews on advanced materials science, 8 (2004) 66.

[20] KONAR, R., PATEK, M. (2015). Prediction of Hardness and Residual Stresses of Dissimilar Weld Joint, Manufacturing Technology, 16/2, (2015), 365-371.

[21] HARDIE, D., CHARLES, E.A., LOPEZ, A.H., Hydrogen embrittlement of high strength pipeline steels, Corrosion Science, 48 (2006) 4378-4385.

[22] TAKAKUWA, O., MANO, Y., SOYAMA, H. (2014). Effect of indentation load on Vickers hardness of austenitic stainless steel after hydrogen charging and changes of mechanical properties by the slow-bend tests, Proc. ASME Pressure Vessel \& Piping Conf, 2014, Paper No. PVP2014-28280, doi:10.1115/PVP2014-28280.

[23] BLACH, J., FALAT, L., ŠEVC, P. (2011). The influence of hydrogen charging[on[the notch tensile properties and fracture behavior of dissimilar weld joints of advanced Cr-Mo-V and[Cr-Ni-Mo creep-resistant steels, Eng. Fail. Anal. 18 (2011), 485-491.

[24] Li, X., WANG, Y., ZHANG, P., LI, B., SONG, X., CHEN, J. (2014). Effect of pre-strain on hydrogen embrittlement of high strength steels, MaterialsScience \& Engineering, A616 (2014) 116-122.

[25] TAKAGI, S., TOJI, Y., HASEGAWA, K., TANAKA, Y., ROESSLER, N., HAMMER, B., HELlER, T. (2010). Hydrogen Embrittlement Evaluation Methods for Ultra-high Strength Steel Sheets for Automobiles, International Journal of Automotive Engineering, 1/2 (2010) 7-13.

[26] DONG, C.F., LIU, Z.Y., LI, X.G., CHENG, Y.F. (2009). Effects of hydrogen-charging on the susceptibility of X100 pipeline steel to hydrogen-induced cracking, Int. J. Hydrogen Energy 34 (2009) 9879-9884.

[27] LOUTHAN, M.R, CASKEY, G.R., DONOVAN, J.A., RAWL, D.E. (1972). Hydrogen embrittlement of metals, Materials Science and Engineering, 10 (1972) 357-368.

[28] TIWARI, G.P., BOSE, A., CHAKRAVARTTY, J.K., WADEKAR, S.L., TOTLANI, M.K., ARYA, R.N., FOTEDAR, R.K. (2000). A study of internal hydrogen embrittlement of steels, Materials Science and Engineering A286 (2000) 269-281. 